Прегледни чланак

623.746:061.1EU(497.5)

doi:10.5937/zrpfns53-21490

Biljana M. Činčurak Erceg, Ph.D., Assistant Professor

Josip Juraj Strossmayer University of Osijek

Faculty of Law Osijek

bcincura@pravos.hr

\title{
LEGAL REGULATION OF UNMANNED AIRCRAFT SYSTEMS IN THE EUROPEAN UNION WITH REFERENCE TO THE LEGISLATION OF THE REPUBLIC OF CROATIA
}

\begin{abstract}
Unmanned aircrafts are rapidly developing, and they are becoming more widespread. The number of unmanned aircraft users is increasing, and it is necessary to harmonise the existing legislation at the EU level and amend the regulatory framework accordingly. In accordance with the development of new solutions within the European Union, the Republic of Croatia amended the 2015 Ordinance on unmanned aircraft systems (Official Gazette, Nos. 49/2015 and 77/2015) in 2018 (Official Gazette, No. 104/2018).

Although the Croatian Civil Aviation Agency stated that the main reason for drafting a new Ordinance was to adjust the national system to the future European Union system in order to facilitate the implementation of the new Regulation on unmanned aircraft operations after its entry into force, it is surprising that the Republic of Croatia decided to amend the Ordinance before the said Regulation was adopted, especially if we know that it takes several years to adopt the European Regulation.

The use of unmanned aircraft systems will certainly increase. However, it should be emphasised that the use of unmanned aircrafts is not a game and that safety rules must be respected. We must commend adjustment of the legal framework aimed at improving the use of unmanned aircratfs. It remains to be seen what the EU will do, what the dynamics will be when we talk about the regulation of unmanned aircrafts and how the Member States will adapt.
\end{abstract}

Keywords: unmanned aircraft, the Croatian Ordinance on unmanned aircraft systems, the Republic of Croatia, European Union, legal regulation. 


\section{INTRODUCTION}

Unmanned vehicles are nowadays used in every mode of transport and imply the use of a vehicle without a crew, without a person on board who operates the vehicle. Bernauw explains that there are two categories of unmanned ('driverless', 'pilotless') vehicles: 1. Remotely Operated Vehicles (ROV) or Remotely Controlled Vehicles $(\mathrm{RCV})^{1}$, and 2. Autonomous Vehicles (AV) ${ }^{2}$.

When speaking of unmanned aircrafts (hereinafter: UA), it should be noted that there is no established terminology regulating this matter. "The current nomenclature for unmanned civilian or military aircraft is varied: drone, unmanned aerial vehicle (UAV), unmanned aircraft system (hereinafter: UAS), remotely piloted aircraft system (hereinafter: RPAS)"3 or remotely piloted aircraft (RPA) as well as unmanned aircraft (UA), Pilotless Aircraft, Pilotless Aerial Vehicles" (PAV), Remotely Operated Aircraft (ROA), and Unmanned Combat Aerial Vehicle (UCAV). "The addition of the word "system" intends to reflect the ancillary remote equipment component required to operate the vehicle as opposed to the aircraft component." The term 'drones' is now firmly established in public parlance.

According to Art. 3, point 30, of Regulation (EU) 2018/1139 of the European Parliament and of the Council of 4 July 2018 on common rules in the field of civil aviation and establishing a European Union Aviation Safety Agency, ${ }^{6}$ "unmanned aircraft means any aircraft operating or designed to operate autonomously or to be piloted remotely without a pilot on board“". Similarly, the Croatian Ordinance

${ }^{1}$ They are "operated in real time by humans, not on board, but external to the craft, from a distance at a remote location, on the basis of interpretation of data collected via an on-board camera, radar, satellite or other means. The remote station can be a ground station, but also an airborne or seaborne station." Kristian Bernauw, "Drones: The Emerging Era of Unmanned Civil Aviation”, Zbornik Pravnog fakulteta u Zagrebu, 2-3/2016, 227.

${ }^{2}$ It is "a robot, self-guided, self-navigating, self-driving, self-steering/self-managing/selfcontrolling/self-governing, on the basis of pre-programmed instructions or artificial intelligence, processing data collected from on-board sensors and from other sources (e.g. radar or satellite tracking). They take decisions about navigation independently, without real-time human command, intervention or input, and are therefore called "autonomous". Ibid.

${ }^{3}$ Biljana Činčurak Erceg, Aleksandra Vasilj, Aleksandar Erceg, “Unmanned Aircrafts ('Drones') - The Need for Legal Regulation and Harmonisation of Legislation in the European Union", SEE | EU Cluster of Excellence in European and International Law - Series of Papers, 3/2018, 10.

${ }^{4} \mathrm{~K}$. Bernauw, 226.

${ }^{5}$ Ibid.

${ }^{6}$ Regulation (EU) 2018/1139 of the European Parliament and of the Council of 4 July 2018 on common rules in the field of civil aviation and establishing a European Union Aviation Safety Agency, and amending Regulations (EC) No 2111/2005, (EC) No 1008/2008, (EU) No 996/2010, (EU) No 376/2014 and Directives 2014/30/EU and 2014/53/EU of the European Parliament and of the Council, and repealing Regulations (EC) No 552/2004 and (EC) No 216/2008 of the European Parliament and of the Council and Council Regulation (EEC) No 3922/91, OJ L 212, 22. 8. 2018, pp. 1-122. 
on unmanned aircraft systems ${ }^{7}$ defines unmanned aircraft as an aircraft used for flights without a pilot on board, that is remotely controlled or programmed and autonomous (Art. 2, point 1). According to the same Ordinance (Art. 2, point 21), an Unmanned Aircraft System is a system consisting of an unmanned aircraft and other equipment, software or add-ons necessary for its remote control.

Unmanned aircrafts are used for various purposes ${ }^{8}$ (surveillance, military, science, research, entertainment, delivery, search, rescue, filming, inspecting infrastructure, environmental monitoring, but can also be used maliciously) and they have great potential which should be exploited. Therefore, it is necessary to adequately regulate their usage. In that sense, when talking about unmanned aircrafts, "general rules or other special rules currently known are not fully applicable, which justifies the creation of specific rules for it."

In literature and the media, the problems with using UAs are highlighted as problems with air transport safety and privacy protection. It is necessary to consider these issues thoroughly and regulate them legally in an appropriate way. Namely, even if the majority of UAs is expected to be operated in safe conditions and by qualified operators, there are areas where uncontrolled access by UAs could cause serious danger and damage. "The use of a drone is generally an activity with increased risk." 10 The use of UAs is not a game and users must be aware of not only the danger they represent, but also possible damage they cause to objects they can collide with, the ground, and people. Other issues such as liability, security, insurance, and environment protection, are not less important, as well as the legal status of the persons involved (a remote pilot, an operator), but they are the subject of another paper.

${ }^{7}$ Ordinance on unmanned aircraft systems, Official Gazette, Nos. 47/2015, 77/2015 and 104/2018.

${ }^{8}$ For examples, see: Kurt W. Smith, "Drone Technology: Benefits, Risks, and Legal Considerations", Seatle Journal of Environmental Law, 1/2015, 293-295, 299-300; Adem Ilker, "Regulating Commercial Drones: Bridging the Gap between American and Europe Drone Regulations", Journal of International Business and Law, 2/2016, 320-324, 326-327; Irena Devčić, "Bespilotne letjelice u službi šumarstva", Hrvatske šume, 253-254/2018, 16-17; Mišo Mudrić, Tihomir Katulić, "Regulacija sustava bespilotnih zrakoplova u hrvatskom, europskom i međunarodnom pravnom okviru", Pravo u gospodarstvu, 2/2016, 127; Aleksandar Erceg, Biljana Činčurak Erceg, Aleksandra Vasilj, "Unmanned Aircraft Systems in Logistics - Legal Regulation and Worldwide Examples toward Use in Croatia", Proceedings of the 17th International Scientific Conference Business Logistics in Modern Management, October 2017 Ekonomski fakultet Osijek, Osijek, 2017, 43-62; Veronika Szikora, Gabor Szilagyi, "New dangerous practice on the horizon? Legal aspects of drone usage“, Зборник радова Правног факултета у Новом Саду, 2/2017, 502, K. Bernauw, 224; European Maritime Safety Agency (EMSA), Possible operational scenarios for RPAS use, http:// www.emsa.europa.eu/operational-scenarios.html, 27 February 2019.

${ }^{9}$ V. Szikora, G. "New dangerous practice on the horizon? Legal aspects of drone usage", Зборник радова Правног факултета у Новом Саду, 2/2017, 518.

${ }^{10} \mathrm{Ibid} ., 509$. 
As UAs are aircrafts, a number of provisions regulating manned aviation apply indiscriminately. However, a revision and improvement of the existing regime at the European level are necessary. Work on the adoption of a Regulation that will regulate the use of UAs in the European Union is still going on, and it does not seem to be over yet. The Republic of Croatia adopted the Ordinance on unmanned aircraft systems in 2015 (Official Gazette, No. 49/2015 and 77/2015), and amended it in 2018 (Official Gazette, No. 104/2018). Namely, amending legislation is absolutely necessary to adapt to the growing unmanned aircraft industry. Considering ongoing work on unmanned aircraft at the European level, the question arises as to whether this new Ordinance is premature.

In this paper, we focus on the adoption of European regulations and the announcement of work that follows. The provisions of the Croatian Ordinance on unmanned aircraft systems is presented in detail and in particular the parts that have been changed. The author also critically addresses the aforementioned provisions.

\section{LEGAL REGULATION OF UNMANNED AIRCRAFTS}

"The legal issues of drones are considered at three levels: international ${ }^{11}$ (International Civil Aviation Organisation ${ }^{12}$ - ICAO), European (European Aviation Safety Agency - EASA), including the European Organisation for the Safety of Air Navigation (EUROCONTROL), Joint Authorities for Rulemaking on Unmanned Systems (JARUS), etc.) and national."13 Since air transport is of particularly international character, the use of UAs should be adjusted accordingly. Therefore, it is necessary to adopt specific regulations and create globally (or at least European) harmonised rules.

Unmanned aircrafts in the European Union are still used under a fragmented regulatory framework since every Member State has its own regulation. There is no regulation de lege lata in the EU, which regulates all unmanned aircrafts in detail, but the EU has been working on this issue in the last few years. European

${ }^{11}$ According to Article 8 of the Convention on International Civil Aviation (the Chicago Convention), no aircraft capable of being flown without a pilot shall be flown without a pilot over the territory of a contracting State without special authorisation by that State and in accordance with the terms of such authorisation. Each contracting State undertakes to ensure that flight of such aircraft without a pilot in region open to civil aircraft shall be so controlled as to obviate danger to civil aircraft. Convention on International Civil Aviation, Official Gazette - International Agreements, No. 1/1996.

${ }^{12}$ It should be mentioned that the ICAO published Circular 328 (2011) on Unmanned Aircraft Systems (UAS) and amended Annexes 2, 7 and 13 to the Chicago Convention to accommodate Remotely Piloted Aircraft Systems (RPAS) intended to be used by international civil aviation.

${ }^{13}$ B. Činčurak Erceg, A. Vasilj, A. Erceg, 13. 
countries are increasingly adopting ordinances governing a legal framework for the implementation of unmanned aircraft system flight operations. Most of the adopted legal frameworks regulate this matter in a similar way and differ according to the categories of unmanned aircrafts, the areas above which flight operations are performed, conditions for flying operations, etc. ${ }^{14}$ The Republic of Croatia was among the first states that regulated unmanned aircrafts.

\subsection{Legal regulation of unmanned aircrafts in the European Union}

Work on the adoption of rules regulating UAs in the European Union is still in progress. The reason why the legislation process has not finished yet can be found in the facts that there are many different stakeholders involved and that unmanned aircrafts evolve every day.

Since work on creating new regulations on UAs is time-consuming and extremely slow, and the procedure is still ongoing because of many changes, in this chapter, we will outline the data that has been repeatedly reported in the literature. Still, steps in drafting a regulation (whose passing is likely to take longer) were announced in early 2019 and will be specifically mentioned. So, although in our opinion, the adoption of regulations is slow, it should be said that it is mainly within the rulemaking programme set by the EASA.

Under the 2015 Aviation Strategy for Europe ${ }^{15}$, the European Commission has proposed a risk-based framework for all types of unmanned aircraft operations, which will ensure their safe use in civil airspace and create legal certainty for the industry. The Regulation will also cover items related to data and privacy protection, security, insurance, liability, and the environment. ${ }^{16}$ The rules must be proportionate to the risk to ensure that new developments are not hampered by unnecessarily heavy and costly rules and procedures.

Regulation (EC) No 216/2008 of the European Parliament and of the Council of 20 February 2008 on common rules in the field of civil aviation and establishing a European Aviation Safety Agency ${ }^{17}$, known as 'the Basic Regulation', mandates the EASA to regulate unmanned aircraft (UA) and remotely piloted aircraft system (RPAS) when used for civil applications and with an operating mass of $150 \mathrm{~kg}$ or

${ }^{14}$ M. Mudrić, T. Katulić, 126.

${ }^{15}$ Communication from the Commission to the European Parliament, the Council, the European Economic and Social Committee and the Committee of the Regions, An Aviation Strategy for Europe, COM (2015) 598 final.

${ }^{16}$ European Commission, Air, Unmanned aircraft (drones), https://ec.europa.eu/transport/ modes/air/uas_en, 2 March 2019.

${ }^{17}$ Regulation (EC) No 216/2008 on common rules in the field of civil aviation and establishing a European Aviation Safety Agency, and repealing Council Directive 91/670/EEC, Regulation (EC) No 1592/2002 and Directive 2004/36/EC, OJ L 79, 19. 3. 2008, pp. 1-49. 
more. According to this Regulation, experimental or amateur-built RPAS, military and non-military governmental RPAS flights, civil RPAS below $150 \mathrm{~kg}$, as well as model aircraft, are regulated by individual Member States. In 2015, the European Commission published the Proposal for a Regulation on common rules in the field of civil aviation, ${ }^{18}$ which provides for new demands in aviation based on past experience and problems encountered (mainly regarding safety and environmental issues). It also contains provisions that create the legal basis to provide for more detailed UA related rules. The European Commission correctly stated in the said Proposal that the current division of competences between the European Union and the Member States regarding UA regulation, which is based on a threshold of $150 \mathrm{~kg}$, is generally deemed to be outdated. The rules applying to UAs should develop towards an operation centric approach, where the risk of operation is made depending on a range of factors. ${ }^{19}$ This operation centric approach means that the focus shifts from the aircraft (aircraft-centred approach) to the particular risk of a particular UA operation.

In the same year, i.e. 2015, the EASA published the Advance Notice of Proposed Amendment (A-NPA 2015-10) and Technical Opinion ${ }^{20}$. The Technical Opinion shows the contents of draft changes to the Basic Regulation and serves as guidance for the Member States to develop or modify UA regulations. It includes 27 concrete proposals for a regulatory framework and low-risk operations of all UAs irrespective of their maximum certified take-off mass (MTOM). This regulatory framework is operation centric, proportionate, ${ }^{21}$ risk-based $^{22}$ and performance-based, ${ }^{23}$ and establishes the following three operation categories, i.e., 'open', 'specific' and 'certified'.

According to the Technical Opinion, considering the risks involved, 'open category' operations require neither an authorisation by the competent authority nor a declaration by the UAS operator before the operation takes place. Safety is ensured through compliance with operational limitations, mass limitations as a proxy of energy, product safety requirements, and a minimum set of operational

${ }^{18}$ Proposal for a Regulation of the European Parliament and of the Council on common rules in the field of civil aviation and establishing a European Union Aviation Safety Agency, and repealing Regulation (EC) No 216/2008 of the European Parliament and of the Council, COM (2015) 0613 final - 2015/0277 (COD).

${ }^{19}$ COM (2015) 0613 final - 2015/0277 (COD), p. 7.

${ }^{20}$ European Aviation Safety Agency, 'Prototype' Commission Regulation on Unmanned Aircraft Operations, https://www.easa.europa.eu/system/files/dfu/UAS\%20Prototype\%20Regulation\%20final.pdf, 2 March 2019.

${ }^{21}$ Proportionality is a key feature of the regulatory framework and means that the operation of UA should be regulated in a manner proportionate to the risk of the specific operation.

${ }^{22}$ The risk-based principle means that the level of risk depends on a range of factors, such as the energy, the size and the complexity of the UA; the population density of the overflown area; the design of the airspace, the density of traffic and the services provided therein.

${ }^{23}$ Performance-based regulation focuses on desired, measurable outcomes instead of focusing on the method or the technical solution. 
rules. In terms of the risks involved, 'specific category' operations do require an authorisation by the competent authority before the operation takes place and consider the mitigation measures identified in an operational risk assessment, except for certain standard scenarios for which a declaration by the UAS operator is sufficient. Considering the risks involved, 'certified category' operations require the certification of the UAS and its operator, as well as flight crew licensing. Requirements are comparable to those for manned aviation. ${ }^{24}$ As stated in the Technical Opinion, the 'open' and 'specific' categories will have priority in rulemaking activities. "The work on the 'certified' category could start as large unmanned aircraft are already within the Agency's scope and today unmanned aircraft can receive a restricted type certificate (RTC) or a permit to fly. The full integration in non-segregated airspace may take some more time as essential technologies are not yet fully mature for implementation." ${ }^{25}$ Further proposals for amending the implementing rules for the 'certified' category need to be aligned with the modifications of the Basic Regulation, progress in technical development and international activities (JARUS, ICAO). ${ }^{26}$

Furthermore, in 2016, the EASA also produced a 'Prototype' Regulation on Unmanned Aircraft Operations that presents a 'prototype' for the operation of unmanned aircraft in the 'open' and 'specific' categories. ${ }^{27}$ "Based on the market's needs, priority has been given to the development of a regulation for operations in the 'open' and 'specific' categories. The development of the regulation framework for operations in the 'certified' category is planned for 2018 and 2019." 28 A 'Prototype' was a first draft of the unmanned aircraft systems regulation. After receiving a great number of comments on the 'Prototype', the EASA published the Notice of Proposed Amendment (NPA) 2017-05 (A) 'Unmanned aircraft system operations in the open and specific categories ${ }^{29}$ in 2017, in which the quality of the 'Prototype' regulation was improved.

${ }^{24}$ European Aviation Safety Agency, Civil drones (Unmanned aircraft), https://www.easa. europa.eu/easa-and-you/civil-drones-rpas, 5 March 2019.

${ }^{25}$ European Aviation Safety Agency, Technical Opinion, Introduction of a regulatory framework for the operation of unmanned aircraft, p. 30. https://www.easa.europa.eu/system/files/ dfu/Introduction\% $200 f \% 20$ a $\% 20$ regulatory $\% 20$ framework $\% 20$ for $\% 20$ the $\% 20$ operation $\% 20$ of\%20unmanned\%20aircraft.pdf, 2 March 2019.

${ }^{26} \mathrm{Ibid}$.

${ }^{27}$ European Aviation Safety Agency, 'Prototype' Commission Regulation on Unmanned Aircraft Operations, https://www.easa.europa.eu/system/files/dfu/UAS\%20Prototype\%20Regulation\%20final.pdf, 2 March 2019. The development of the NEP for operations in 'certified' category is planned for 2019 and the beginning of 2020.

${ }^{28}$ European Aviation Safety Agency, Drones - regulatory framework background, https:// www.easa.europa.eu/easa-and-you/civil-drones-rpas/drones-regulatory-framework-background, 9 March 2019.

${ }^{29}$ European Aviation Safety Agency, Notice of Proposed Amendment 2017-05 (A), https:// www.easa.europa.eu/system/files/dfu/NPA\%202017-05\%20\%28A\%29_0.pdf, 2 March 2019. 
Other measures for the use of UAs have also been undertaken. In June 2017, the Single European Sky Air Traffic Management Research Joint Undertaking (SESAR Joint Undertaking), whose role is to develop the new generation European air traffic management system, presented its blueprint to make UA use in low-level airspace safe, secure and environmentally friendly. This "U-Space" covers altitudes of up to 150 metres. $^{30}$

As already stated, pursuant to Regulation (EC) No 216/2008, the regulation of civil UAS with MTOMs of less than $150 \mathrm{~kg}$ falls within the competence of the EU Member States. “On 22 December 2017, Member States endorsed an agreement reached with the European Parliament for the revision of the Basic Regulation, extending the competence of the EU to all UAS, except those used for 'state' operations (e.g. military, customs, police, firefighting, etc.), and defining the essential requirements to ensure the safety of UAS. In addition, the said Regulation includes the possibility of 'opting in' for MSs wishing to place 'state' UAS under EU regulation." ${ }^{31}$ Lastly, Regulation (EU) 2018/1139 of the European Parliament and of the Council on common rules in the field of civil aviation and establishing a European Union Aviation Safety Agency ${ }^{32}$ was adopted in July 2018. Unmanned aircrafts are regulated, among others, by Art. 55 (Essential requirements for UA), Art. 56 (Compliance of UA), Art. 57 (Implementing acts as regards UA), Art. 58 (Delegated powers) as well Annex IX (The design, production, maintenance and operation of aircraft).

According to Regulation (EU) 2018/1139, UA related rules provide the basic principles to ensure safety, security, privacy and the protection of personal data. Higher-risk UA operations will require certification, while UA presenting the lowest risk will simply need to conform to the normal EU market surveillance mechanisms. ${ }^{33}$ The other detailed rules on UA will be set by the Commission with the help of the EASA, based on the principles outlined in this Regulation.

${ }^{30}$ European Commission, Aviation: Commission is taking the European drone sector to new heights, https://ec.europa.eu/transport/modes/air/news/2017-06-16-aviation-commission-takingeuropean-drone-sector-new-heights_en, 9 March 2019. See also SESAR Joint Undertaking, U-space Blueprint, https://www.sesarju.eu/u-space-blueprint, 9 March 2019.

${ }^{31}$ European Aviation Safety Agency, Opinion No. 01/2018, Introduction of a regulatory framework for the operation of unmanned aircraft systems in the 'open' and 'specific' categories, $\mathrm{p}$. 5, https://www.easa.europa.eu/sites/default/files/dfu/Opinion\%20No\%2001-2018.pdf, 9 March 2019.

${ }^{32}$ Regulation (EU) 2018/1139 of the European Parliament and of the Council of 4 July 2018 on common rules in the field of civil aviation and establishing a European Union Aviation Safety Agency, and amending Regulations (EC) No 2111/2005, (EC) No 1008/2008, (EU) No 996/2010, (EU) No 376/2014 and Directives 2014/30/EU and 2014/53/EU of the European Parliament and of the Council, and repealing Regulations (EC) No 552/2004 and (EC) No 216/2008 of the European Parliament and of the Council and Council Regulation (EEC) No 3922/91, OJ L 212, 22. 8. 2018, pp. $1-122$.

${ }^{33}$ European Council, Council of the European Union, Updated aviation safety rules and new rules on drones approved by the Council, https://www.consilium.europa.eu/en/press/press-releases/ 
In order to ensure the uniform implementation of and compliance with the essential requirements the Commission must adopt implementing acts ${ }^{34}$, laying down detailed provisions concerning the specific rules and procedures, inter alia: for the operation of UA as well as for the personnel, including remote pilots, and organisations involved in those operations; for issuing, maintaining, amending, limiting, suspending, or revoking the certificates, or for making declarations, for the operation of UA; for the registration and marking of UA and for the registration of operators; for establishing national registration systems, the privileges and responsibilities of the holders of certificates and of natural and legal persons making declarations (see Art. 57 of the Regulation (EU) 2018/1139). The work on Implementing Act is still in progress, and we hope that it may be passed before the deadline, due to legal certainty and quicker harmonisation/unification of the rules.

For the design, production and maintenance of UA, their engines, propellers, parts, non-installed equipment and equipment to control the aircraft remotely, as well as for the personnel, including remote pilots and organisations involved in those activities, the Commission is empowered to adopt delegated acts, laying down detailed rules as defined in Art. 58 of Regulation (EU) 2018/1139.

It must be mentioned that according to Art. 56(8), Member States can "lay down national rules to make subject to certain conditions the operations of unmanned aircraft for reasons falling outside the scope of the Regulation, including public security or protection of privacy and personal data in accordance with the Union law".

Annex IX to Regulation (EU) 2018/1139 regulates essential requirements for the design, production, maintenance and operation of unmanned aircraft (obligations for the operator and the remote pilot ${ }^{35}$, organisation ${ }^{36}$ ); additional essential requirements for the design, production, maintenance and operation of unmanned aircraft that must be met to ensure safety for people on the ground and other airspace users during the operation of unmanned aircraft, taking into account the level of risk of the operation as necessary: airworthiness, ${ }^{37}$ organisations, persons

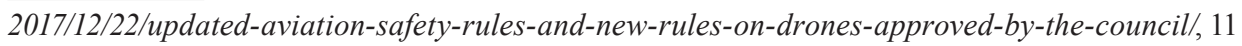
March 2019.

${ }^{34}$ Let us mention here that according to Art. 140(2) of Regulation (EU) 2018/1139, the implementing rules adopted on the basis of Regulations (EC) No 216/2008 and (EC) No 552/2004 shall be adapted to Regulation 2018/1139 no later than 12 September 2023.

${ }^{35}$ In Art. 3, point 31, Regulation (EU) 2018/1139 defines a remote pilot as "a natural person responsible for safely conducting the flight of an unmanned aircraft by operating its flight controls, either manually or, when the unmanned aircraft flies automatically, by monitoring its course and remaining able to intervene and change the course at any time."

36 The organisation responsible for the production or marketing of the unmanned aircraft must provide information to the operator of an unmanned aircraft.

${ }^{37}$ According to Annex IX, point 2.1.1. and point 2.1.4., UA "must be designed in a way that, or contain features or details that, the safety of the person operating the unmanned aircraft or of 
involved in the operation of unmanned aircraft, operations; essential environmental requirements as set out in Annex III to Regulation (EU) 2018/1139; essential requirements for the registration of UA and their operators and marking of UA.

According to Annex IX, point 1.1, the operator and the remote pilot of UA "must be aware of the applicable Union and national rules relating to the intended operations, in particular regarding safety, privacy, data protection, liability, insurance, security and environmental protection. The operator and the remote pilot must be able to ensure the safety of operation and safe separation of the unmanned aircraft from people on the ground and from other airspace users. This includes good knowledge of the operating instructions provided by the producer, of safe and environmentally-friendly use of unmanned aircraft in the airspace, and of all relevant functionalities of the unmanned aircraft and applicable rules of the air and ATM/ANS procedures." A UA must be designed and constructed so that it is fit for its intended function, and can be operated, adjusted and maintained without putting persons at risk.

Pursuant to essential requirements for the registration of a UA and their operators, as prescribed in Annex IX, a UA the design of which is subject to certification has to register in accordance with the implementing acts. Operators of UA have to register in accordance with the implementing acts, where they operate: a) UA which, in the case of impact, can transfer, to a human, kinetic energy above 80 Joules; b) UA the operation of which presents risks to privacy, protection of personal data, security or the environment; c) UA the design of which is subject to certification (Annex IX, point 4. 2.). Where a requirement of registration applies pursuant to Annex IX, point 4.1 or 4.2 , the UA concerned shall be individually marked and identified, in accordance with the implementing acts.

After the consultation period on the NPA 2017-05, the EASA published the Opinion $^{38}$ in January 2018, including a proposal for a new Regulation referring to UAS operations in the 'open' and 'specific' categories (for more information about the 'open', 'specific' and 'certified operation categories, see supra). The Opinion is submitted to the European Commission to be used as a technical basis for preparing EU regulations. The proposed Regulation will be accompanied by appropriate Alternative Means of Compliance (AMC) and Guidance Material (GM) in 2019. The proposed Regulation provides for a framework to safely operate UAS while respecting the development of the industry, defines the technical and operational

third parties in the air or on the ground, including property, can be satisfactorily demonstrated." UA and their engines, propellers, parts, non-installed equipment, and equipment to control the UA remotely "must function as intended under any foreseeable operating conditions, throughout, and sufficiently beyond, the operation for which the aircraft was designed."

${ }^{38}$ European Aviation Safety Agency, Opinion No. 01/2018, Introduction of a regulatory framework for the operation of unmanned aircraft systems in the 'open' and 'specific' categories, https://www.easa.europa.eu/sites/default/files/dfu/Opinion\%20No\%2001-2018.pdf, 9 March 2019. 
requirements for the UAS and pilot qualifications, combines product legislation and aviation legislation, ${ }^{39}$ allows a high degree of flexibility for the EASA Member States, ${ }^{40}$ and provides special alleviations for people flying model aircraft. ${ }^{41}$ In February 2019, the EASA Committee gave its positive vote to the European Commission's proposal for an Implementing Act regulating the operations of UAS in the open and specific categories. The Delegated act which contains the technical requirements for UAS including the requirements for the CE marking of the UAS in the open category was adopted by the European Commission on 12 March 2019. "If no objections are raised by the EU Parliament or by the EU Council, both acts will be published before the summer of 2019 and the regulation will become gradually applicable within a year of publication. By 2022 the transitional period will be completed, and the regulation will be fully applicable."42

As already mentioned, Regulation (EU) 2018/1139 mandates the EASA to create legislation or basic rules that apply across the EU. The EASA continues its work that will enable safe operations of UAS and their integration into the airspace. ${ }^{43}$ "It is not meant to be a catchall for all drones and all rules across the EU, but rather a starting point for EU drone rules and a building block for standards in the Member States." ${ }^{44}$ Furthermore, according to transitional provisions, Art. 140(3), relevant provisions of Regulation (EC) No 216/2008 continue to apply until the delegated and the implementing acts of Regulation 2018/1139 enter into force. In practice, this

${ }^{39}$ Design requirements for small UA will be implemented by using the legislation relative to making products available on the market (CE marking). The standard CE mark will be accompanied by the identification of the class of the UA (from C0 to C4) and by a do's and don'ts consumer information that will be found in all UA boxes. Based on the UA class an operator will know in which area he can operate and what competence is required. The proposal allows a high degree of flexibility for EASA Member States which will be able to define zones in their territory where either UA operations are prohibited or restricted, or where certain requirements are alleviated. European Aviation Safety Agency, Drones - regulatory framework background, https://www.easa. europa.eu/easa-and-you/civil-drones-rpas/drones-regulatory-framework-background, 9 March 2019.

${ }^{40}$ They will be able to define zones in their territory where either UA operations are prohibited or restricted or where certain requirements are alleviated. Ibid.

${ }^{41}$ Ibid.

${ }^{42}$ European Aviation Safety Agency, Civil drones (Unmanned aircraft), https://www.easa. europa.eu/easa-and-you/civil-drones-rpas, 14 March 2019.

${ }^{43}$ EASA is working on the Opinion with 2 standards scenarios declarative which will be an appendix to the Implementing Act, the Notice of Proposed Amendment (NPA) for the UAS in the Certified Category which will include a comprehensive package addressing all aviation domains (airworthiness, continuing airworthiness, remote pilot license, aircraft operations and aerodromes) and the Opinion of U-space including a high level framework. European Aviation Safety Agency, Civil drones (Unmanned aircraft), https://www.easa.europa.eu/easa-and-you/civil-drones-rpas, 5 March 2019.

${ }^{44}$ DroneRules, European Council Passes New Regulation for Aviation Safety, http://dronerules.eu/en/recreational/news/european-council-passes-new-regulation-for-aviation-safety, 5 March 2019. 
means that national regulations ruling today's operations of UA lighter than $150 \mathrm{~kg}$ will be progressively replaced in 2019 and 2020 by new European legislation.

Incorporating UA into controlled airspace is a demanding and long-lasting process, as can be seen from the aforementioned overview of UA regulations in the European Union. Here, it was necessary not only to adopt rules on UA, but also to amend the Regulation on common rules in the field of civil aviation. A new regulation is also needed in order to meet all safety requirements for the use of UA. After several years of preparation, consultations with numerous stakeholders and work on drafting the text, a new Regulation (EU) 2018/1139 of the European Parliament and of the Council on common rules in the field of civil aviation and establishing a European Union Aviation Safety Agency was finally adopted in 2018.

This Regulation now applies to unmanned aircrafts regardless of their operating mass, since UAs operate within the airspace alongside manned aircraft. However, Member States will have a degree of flexibility to implement a risk-based approach and the principle of proportionality in operations. The adoption of the implementing and delegated acts follows. Finally, these rules should result in the harmonised legislation of EU Member States.

\subsection{Legal regulation of unmanned aircrafts in the Republic of Croatia}

All civil aviation activities carried out on the territory and in the airspace of the Republic of Croatia are regulated by the Air Traffic Act. ${ }^{45}$ It does not regulate in detail the rules for the use of UA, but only prescribes a general provision that conditions for the safe use of UAs, UAS and model aircrafts and conditions for persons involved in the operation of these aircrafts and systems shall be established by a regulation adopted pursuant to the Air Traffic Act or by EU regulations (Art. 93a).

As already stated, the Republic of Croatia adopted the Ordinance on unmanned aircraft systems in 2015 and amended it in 2018. The Croatian Civil Aviation Agency (CCAA) stated that the main reason for drafting this new Ordinance is to adjust the national system to the future EU system in order to facilitate the implementation of the new Regulation on UA operations when it enters into force ${ }^{46}$. It is surprising that the Republic of Croatia has decided to amend the Ordinance before the said Regulation was adopted. In what follows, the provisions of both ordinances are compared and analysed.

${ }^{45}$ Official Gazette, Nos. 69/2009, 84/2011, 54/2013 and 92/2014.

${ }^{46}$ Hrvatska agencija za civilno zrakoplovstvo, Pravilnik o sustavima bespilotnih zrakoplova i Pravilnik o izmjenama i dopunama Pravilnika o upravljanju zračnim prostorom, http://www. ccaa.hr/hrvatski/detalji-novosti_31/pravilnik-o-sustavima-bespilotnih-zrakoplova-i-pravilnik-oizmjenama-i-dopunama-pravilnika-o-upravljanju-zracnim-prostorom_984/, 13 March 2019. 
In accordance with Article 1(1), the Ordinance of 2018 prescribes the requirements for the safe use of unmanned aircraft with an operating mass of $150 \mathrm{~kg}$ and less and the requirements for the persons taking part in the operation of these aircrafts. Pursuant to Article 2(2), the provisions of the Ordinance shall not apply to unmanned aircraft when: a) they are used for military, customs or police activities, search and rescue, firefighting, border control and coast guarding, or similar activities undertaken in the public interest, or b) when used indoors. In this place, we mention that conditions for aerial photography flights are defined by the Regulation on Aerial Photography ${ }^{47}$ and not by the Ordinance on unmanned aircraft systems. The Ordinance no longer prescribes technical and operational conditions, as was regulated by the Ordinance of 2015. By comparing the legal definitions in both ordinances, it can be concluded that the Ordinance of 2018 is more precise, linguistically aligned and clearer.

The Ordinance differentiates unmanned aircraft ${ }^{48}$ from an unmanned aircraft system $^{49}$ (UAS). According to Art. 3(1), UA must be marked with an identification label (applicable to UA weighing less than $5 \mathrm{~kg}$ ) or a non-flammable identification plate containing the name, address and other operator or owner contact information) by the operator ${ }^{50}$. In particular, the flight rules and duties and responsibilities of a remote pilot $^{51}$ are regulated.

${ }^{47}$ Uredba o snimanju iz zraka, Official Gazette, No. 70/2016.

${ }^{48}$ In accordance with Art. 2, point 1 of the Ordinance, an unmanned aircraft is an aircraft intended for the conduct of flight without a pilot on board, which is either remotely controlled or programmed and autonomous.

49 According to point 21, an unmanned aircraft system (UAS) is a system that consists of unmanned aircraft and other equipment, software or add-ons necessary for its remote control.

${ }^{50}$ Operator is a natural or legal person engaged in flight operations by a UAS (Art. 2, point 15). Operator duties and responsibilities pursuant to Art. 9 of the Ordinance are to ensure that flight operations are conducted in accordance with applicable regulations, the Flight Manual or Instructions for Use and the Operations Manual when applicable, that flight operations are conducted without endangering life, health or property on the ground or in the air, and without disturbing the public order and peace, as well as that the remote pilot has received the correct instructions, has demonstrated the ability to conduct flight operations and is aware of responsibilities and the relation of such tasks with the operation as a whole. The operator establishes a reporting system on safety related events in civil aviation according to the applicable regulation.

${ }^{51}$ Remote pilot is a natural person responsible for the safe conduct of a UA flight by operating its flight controls, either by manual use of remote control, or when an unmanned aircraft flies automatically, by monitoring its course with the possibility of intervention and a change of direction at any time. In terms of provisions of the Air Traffic Act, a remote pilot is considered to be the pilot-in-command, (Art. 2, point 16). Pursuant to Art. 15, mandatory documentation that the remote pilot must have when performing flight operations includes the Flight Manual or Instructions for Use of UAS, the original or a certified true copy of the Croatian Civil Aviation Agency (CCAA) Approval (if applicable), the insurance policy issued in accordance with a dedicated regulation, and the Operations Manual (if applicable). Duties and responsibilities of a remote pilot are prescribed in Article 5. 
Rules for flying are prescribed in Art. 4 of the Ordinance. ${ }^{52}$ It is not allowed to transport dangerous goods, freight, people or animals with UA, drop items during the flight, and conduct a flight over an assembly of people (Art. 4(3)). Numerous exceptions to the rules set out in Art. 4 are listed in Art. 7 of the Ordinance.

Flight operation categorisation and derogations to flight operations have been changed in relation to the Ordinance of $2015 .{ }^{53}$ Now, there are five flight operation categories, i.e., $\mathrm{A}, \mathrm{B} 1, \mathrm{~B} 2, \mathrm{C} 1$ and $\mathrm{C}_{2}^{54}$, as prescribed in the Ordinance on unmanned

52 Pursuant to Art. 4(1), it is allowed to fly a UA: a) by day, b) in uncontrolled airspace up to $120 \mathrm{~m}$ above the surface or up to $50 \mathrm{~m}$ above the obstacle, whichever is greater, c) in controlled airspace outside a radius of $5 \mathrm{~km}$ from the aerodrome reference point up to $50 \mathrm{~m}$ above the surface, d) at a distance of at least $3 \mathrm{~km}$ from thresholds and edges of an uncontrolled airport runway, except where specific procedures for the flights of UA are defined in the airport's instructions for use, e) in such a way that the horizontal distance of a UA from an assembly of people is not less than $50 \mathrm{~m}$, except when a UA is taking part in a flying display, f) in such a way that the horizontal distance from uninvolved people is not less than the flight altitude and not less than i) $5 \mathrm{~m}$ when the lowspeed mode is activated on the UA, and when the maximum speed of $3 \mathrm{~m} / \mathrm{s}$ is set, or ii) $30 \mathrm{~m}$ in all other cases, g) in visual line of sight, and h) upon establishment of the ad hoc structure in accordance with the applicable airspace management regulation. See also Art. 7 for the exceptions to these rules. For more information about the establishment of the ad hoc structure, see the Ordinance on Airspace Management, Official Gazette, Nos. 32/2018, 104/2018.

${ }^{53}$ In terms of operating mass, according to Art. 3 of the Ordinance of 2015, unmanned aircrafts were divided into three classes (1. Class 5: to 5 kilograms, 2. Class 25: from 5 kilograms to 25 kilograms, 3. Class 150: from 25 kilograms to and including 150 kilograms). Flight areas were classified in relation to buildings, population, and the presence of people (Class I, Class II, Class III and Class IV). In accordance with Annex 1 of the Ordinance of 2015, the flight operations category was determined by the level of risk that their performance represents for the environment. A combination of operating mass and a flight area defined one of the four categories of flight operations (A, B, C and D.)

${ }^{54}$ Category A - operating mass is less than $250 \mathrm{~g}$ and the highest speed is less than $19 \mathrm{~m} / \mathrm{s}$. Flight operation can be conducted during the day and/or at night in an unpopulated and/or a populated area. There are no requirements for the minimum age of the remote pilot and taking theoretical/practical exams. There are also no requirements for the operator.

Category $\mathrm{B} 1-250 \mathrm{~g} \leq \mathrm{OM} \leq 900 \mathrm{~g}$ and the highest speed is less than $19 \mathrm{~m} / \mathrm{s}$. Flight operation can be conducted during the day in an unpopulated area. The minimum age of the remote pilot is 14 years or less than 14 years but under adult supervision. There are no requirements for taking theoretical/practical exams. There are no requirements for the operator.

Category B2 - OM $<5 \mathrm{~kg}$, no speed limits. Flight operation can be conducted during the day and/or at night in an unpopulated and/or a populated area. The minimum age of the remote pilot is 16 years. There are no requirements for taking theoretical/practical exams. The operator must be registered. There are no requirements for operator documentation.

Category $\mathrm{C} 1-5 \mathrm{~kg} \leq \mathrm{OM}<25 \mathrm{~kg}$, no speed limits. Flight operation can be conducted during the day in an unpopulated area. The minimum age of the remote pilot is 18 years. The remote pilot must pass theoretical knowledge examinations provided by the CCAA. The operator must be registered. There are no requirements for operator documentation.

Category $\mathrm{C} 2-5 \mathrm{~kg} \leq \mathrm{OM} \leq 150 \mathrm{~kg}$, no speed limits. Flight operation can be conducted during the day and/or at night in an unpopulated and/or a populated area. The minimum age of the remote pilot is 18 years. The remote pilot must pass theoretical knowledge examinations provided 
aircraft systems, Article 6, Table 1. Each of these categories is defined by the UA operating mass and the maximum speed according to the manufacturer's technical specifications. For each category, the following is defined: when (day/night) and where (unpopulated/populated area) flight operations are permitted, the requirements for the remote pilot (the minimum age and the necessity of taking theoretical/practical exams) and the requirements for the operator (obligation to register/approve the operator and operator documentation).

The most criticised provisions of the Ordinance of 2015 are: one on flight during daylight (Art. 11(2), point a) as it disables the full exploitation of the technological capabilities of unmanned aircrafts; a provision on the absence of a UAS register ${ }^{55}$ and provisions on technical requirements relating to flight operations ${ }^{56}$ (operator age, the psychophysical ability, knowledge of the aviation regulations and the ability to manage the system depending on the category of flight operations). Were there any changes in relation to these issues? In its Art. 13(1), the Ordinance of 2018 prescribes that the Croatian Civil Aviation Agency (CCAA) keeps records of unmanned aircraft operators. However, there is no obligation for all operators to register (A and B1 flight operations categories are excluded from the registration obligation). ${ }^{57}$ Pursuant to Art. 4(1) point a) of the Ordinance, it is allowed to fly a UA during the day; however, in accordance with Art. 7(1), flight operations may also be conducted at night in A, B2, and C2 flight operations categories. In this case, a UA must be equipped with lights that ensure the determination of orientation of the UA in airspace, and these lights must be visible to the remote pilot during the whole flight. ${ }^{58}$ Requirements to conduct flight operations are not strict (see supra the description of all five flight operations categories), and the Croatian Ordinance is pretty liberal in this part. Therefore, we stress concerns related to the safety of conducting flights, especially in A, B1 and B2 categories.

When analysing the provisions relating to UA, we believe it is necessary to set out clear rules referring to the requirements for the operator and the remote pilot. The operator and the remote pilot ${ }^{59}$ are responsible for the entire flight operation

by the CCAA and demonstrate flight preparation and flying. The operator needs approval. The operator has to take care of the following: a) the operations manual, b) flight records, and c) safety risk assessment.

${ }^{55}$ See M. Mudrić, T. Katulić, 147, and B. Činčurak Erceg, A. Vasilj, A. Erceg, 19.

${ }^{56}$ A. Erceg, B. Činčurak Erceg, A. Vasilj, 54.

${ }^{57}$ Ordinance on unmanned aircraft systems, Art. 6, Table 1.

${ }^{58}$ Ordinance on unmanned aircraft systems, Art. 8.

${ }^{59}$ According to Art. 5(1) of the Ordinance, a remote pilot shall: a) operate an UA in a safe manner, without jeopardizing life, health or property on the ground or in the air, and without disturbing the public order and peace, b) operate an UA in accordance with applicable regulations, the Flight Manual or Instructions for Use and the Operations Manual, when applicable, c) check the integrity of the UAS before flight, d) check if the UA is marked, e) secure the perimeter of the take-off and landing area, f) collect all necessary information for the planned flight and make 
and for the safe conduct of the flight, respectively. The operator and the remote pilot may be the same person. The main questions regarding the flight are as follows: where is it allowed to conduct the flight, what rules must be respected, what are the requirements for the operator and the remote pilot, what is allowed and what is not allowed, and is it necessary to register UA or to get an approval. Therefore, it is of great importance to educate any person who wants to use UA and raise awareness of conducting the flight in a safe manner. Since this paper provides an overview of the European and the Croatian regulation regarding UA, a detailed analysis of these issues is a topic for further research and another paper.

Considering ongoing legislative work at the European level, amendments to the Ordinance will be required.

\section{CONCLUSION}

Unmanned aircraft operates within the airspace together with manned aircraft; therefore, they must be regulated in an appropriate manner. In accordance with Regulation (EC) No 216/2008 (the Basic Regulation), the regulation of unmanned aircraft systems (UAS) with a maximum take-off mass of less than $150 \mathrm{~kg}$ was within the competence of the EU Member States which led to a fragmented regulatory system. With the adoption of the 'new' Basic Regulation (Regulation (EU) 2018/1139), the EU became competent for all UA, irrespective of their mass. Thus, it is necessary to adopt a whole new set of rules (specific rules and procedures for the operation of UA; the rules and procedures for issuing, maintaining, amending, limiting, suspending, or revoking the certificates; the rules and procedures for the registration and marking of UA and for the registration of UA operators; the requirements for the design and manufacture of UAS, etc).

The work of the European Aviation Safety Agency (EASA) on drafting a regulation on UA and consequently on developing harmonised European rules is significant. However, the final adoption of the regulation will require some more time. Harmonised rules for safe UA operation should bring legal certainty for users (operators, remote pilots), the UA industry, persons involved in air transport and all citizens who can be harmed by using UA. It will take some more time to adopt European regulation on rules and procedures for the operation of UA. Unmanned aircraft operations are subject to rules that are proportionate to the risk of a particular operation or type of operations. The operations of UAS in Europe will be

sure that weather and other conditions in the flight area ensure the safe flight conduct, g) ensure that all equipment or cargo is properly attached to an UA in a way to prevent an unintentional fall, h) operate an UA in a manner to clear all obstacles during take-off or landing, i) constantly scan the airspace in which the flying of UA is conducted so as not to endanger other aircraft, and j) give way to manned aircraft. 
classified into 3 main categories: 1 . the 'open' category that, considering the risks involved, requires neither a prior authorisation by the competent authority nor a declaration by the UAS operator before the operation takes place; 2. the 'specific' category that requires an authorisation by the competent authority before the operation takes place, and 3. the 'certified' category that requires the certification of the UA, a licensed remote pilot and an operator approved by the competent authority, in order to ensure an appropriate level of safety.

As mentioned in the paper, relevant provisions of Regulation (EC) No 216/2008 continue to apply until the delegated acts and the implementing acts of Regulation 2018/1139 enter into force. In practice, this means that national regulations ruling today's operations of UAS lighter than $150 \mathrm{~kg}$ will be applied and progressively replaced in the coming years by the new European legislation. Although we will have a fragmented regulatory framework for UA for some time, we hope that it will not last long.

The Republic of Croatia was among the first states that have regulated UA. As already stated, the Republic of Croatia adopted the Ordinance on unmanned aircraft systems in 2015 and amended it in 2018. The new Ordinance extends its application to UA regardless of the kinetic energy it can achieve, amends the general conditions referring to UA flights (flight at night, flight near the airport, flight over a group of people, limitation of flight height, the distance from people, etc.) and no longer prescribes technical requirements for performing flight operations. Since the adoption of rules at the European level is still in progress, in our opinion, changes of the Croatian Ordinance may have been premature. The adoption of new European regulations will certainly require national re-amendment.

Adopting the new rules and their implementation will certainly contribute to the harmonisation of regulation. However, Member States must have a degree of flexibility regarding UA operations. In order to conduct flight operations in a safe and secure way, we advocate the necessity of education for all UA users and subjects involved.

\section{REFERENCES}

\section{Books and articles}

Kristian Bernauw, "Drones: The Emerging Era of Unmanned Civil Aviation", Zbornik Pravnog fakulteta u Zagrebu, 2-3/2016, 223-248.

Biljana Činčurak Erceg, Aleksandra Vasilj, Aleksandar Erceg, "Unmanned Aircrafts ('Drones') - The Need for Legal Regulation and Harmonisation of Legislation in the European Union", SEE $\mid$ EU Cluster of Excellence in European and International Law - Series of Papers, 3/2018, 9-21.

Irena Devčić, "Bespilotne letjelice u službi šumarstva", Hrvatske šume, 253-254/2018, $16-17$. 
Aleksandar Erceg, Biljana Činčurak Erceg, Aleksandra Vasilj, "Unmanned Aircraft Systems in Logistics - Legal Regulation and Worldwide Examples toward Use in Croatia", Proceedings of the 17th International Scientific Conference Business Logistics in Modern Management, October 2017 Ekonomski fakultet Osijek, Osijek, 2017, 43-62.

Adem Ilker, "Regulating Commercial Drones: Bridging the Gap between American and Europe Drone Regulations", Journal of International Business and Law, 2/2016, 313-335.

Mišo Mudrić, Tihomir Katulić, "Regulacija sustava bespilotnih zrakoplova u hrvatskom, europskom i međunarodnom pravnom okviru", Pravo u gospodarstvu, 2/2016, $123-158$.

Kurt W. Smith, "Drone Technology: Benefits, Risks, and Legal Considerations", Seatle Journal of Environmental Law, 1/2015, 290-301.

Veronika Szikora, Gabor Szilagyi, "New dangerous practice on the horizon? Legal aspects of drone usage“, Зборник радова Правног̄ факулиетеиа у Новом Саду, 2/2017, 499-519.

\section{Legislative acts}

Communication from the Commission to the European Parliament, the Council, the European Economic and Social Committee and the Committee of the Regions, An Aviation Strategy for Europe, COM (2015) 598 final.

Proposal for a Regulation of the European Parliament and of the Council on common rules in the field of civil aviation and establishing a European Union Aviation Safety Agency, and repealing Regulation (EC) No 216/2008 of the European Parliament and of the Council, COM (2015) 0613 final - 2015/0277 (COD).

Regulation (EC) No 216/2008 on common rules in the field of civil aviation and establishing a European Aviation Safety Agency, and repealing Council Directive 91/670/EEC, Regulation (EC) No 1592/2002 and Directive 2004/36/EC, OJ L 79, 19. 3. 2008, pp. 1-49.

Regulation (EU) 2018/1139 of the European Parliament and of the Council of 4 July 2018 on common rules in the field of civil aviation and establishing a European Union Aviation Safety Agency, and amending Regulations (EC) No 2111/2005, (EC) No 1008/2008, (EU) No 996/2010, (EU) No 376/2014 and Directives 2014/30/EU and 2014/53/EU of the European Parliament and of the Council, and repealing Regulations (EC) No 552/2004 and (EC) No 216/2008 of the European Parliament and of the Council and Council Regulation (EEC) No 3922/91, OJ L 212, 22. 8. 2018, p. 1-122.

Konvencija o međunarodnom civilnom zrakoplovstvu (Convention on International Civil Aviation), Official Gazette - International Agreements, No. 1/1996.

Pravilnik o sustavima bespilotnih zrakoplova (Ordinance on unmanned aircraft systems), Official Gazette, Nos. 47/2015, 77/2015 and 104/2018.

Pravilnik o upravljanju zračnim prostorom (Ordinance on Airspace Management), Official Gazette, Nos. 32/2018 and 104/2018.

Uredba o snimanju iz zraka (Regulation on Aerial Photography), Official Gazette, No. $70 / 2016$. 
Zakon o zračnom prometu (Air Traffic Act), Official Gazette, Nos. 69/2009, 84/2011, $54 / 2013$ and $92 / 2014$.

\section{Website references}

DroneRules, European Council Passes New Regulation for Aviation Safety, http:// dronerules.eu/en/recreational/news/european-council-passes-new-regulationfor-aviation-safety, 5 March 2019.

European Aviation Safety Agency, 'Prototype' Commission Regulation on Unmanned Aircraft Operations, https://www.easa.europa.eu/system/files/dfu/UAS\%20Prototype\%20Regulation\%20final.pdf, 2 March 2019.

European Aviation Safety Agency, Civil drones (Unmanned aircraft), https://www. easa.europa.eu/easa-and-you/civil-drones-rpas, 5 March 2019.

European Aviation Safety Agency, Civil drones (Unmanned aircraft), https://www. easa.europa.eu/easa-and-you/civil-drones-rpas, 14 March 2019.

European Aviation Safety Agency, Drones - regulatory framework background, https://www.easa.europa.eu/easa-and-you/civil-drones-rpas/drones-regulatoryframework-background, 9 March 2019.

European Aviation Safety Agency, Notice of Proposed Amendment 2017-05 (A), https: //www.easa.europa.eu/system/files/dfu/NPA\%202017-05\%20\%28A\%29_0.pdf, 2 March 2019.

European Aviation Safety Agency, Opinion No. 01/2018, Introduction of a regulatory framework for the operation of unmanned aircraft systems in the 'open' and 'specific' categories, https://www.easa.europa.eu/sites/default/files/dfu/Opinion\%20No\%2001-2018.pdf, 9 March 2019.

European Aviation Safety Agency, Technical Opinion, Introduction of a regulatory framework for the operation of unmanned aircraft, https://www.easa.europa.eu/ system/files/dfu/Introduction\%20 of\%20a\%20regulatory\%20framework\%20 for\%20the\%20operation\%20of\%20unmanned\%20aircraft.pdf, 2 March 2019.

European Commission, Air, Unmanned aircraft (drones), https://ec.europa.eu/transport/modes/air/uas_en, 2 March 2019.

European Commission, Aviation: Commission is taking the European drone sector to new heights, https://ec.europa.eu/transport/modes/air/news/2017-06-16-aviation-commission-taking-european-drone-sector-new-heights_en, 9 March 2019.

European Council, Council of the European Union, Updated aviation safety rules and new rules on drones approved by the Council, https://www.consilium.europa. eu/en/press/press-releases/2017/12/22/updated-aviation-safety-rules-and-newrules-on-drones-approved-by-the-council/, 11 March 2019.

European Maritime Safety Agency (EMSA), Possible operational scenarios for RPAS use, http://www.emsa.europa.eu/operational-scenarios.html, 27 February 2019.

Hrvatska agencija za civilno zrakoplovstvo, Pravilnik o sustavima bespilotnih zrakoplova i Pravilnik o izmjenama i dopunama Pravilnika o upravljanju zračnim prostorom, http://www.ccaa.hr/hrvatski/detalji-novosti_31/pravilnik-o-sustavimabespilotnih-zrakoplova-i-pravilnik-o-izmjenama-i-dopunama-pravilnika-oupravljanju-zracnim-prostorom_984/, 13 March 2019.

SESAR Joint Undertaking, U-space Blueprint, https://www.sesarju.eu/u-space-blueprint, 9 March 2019. 


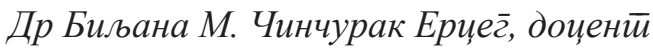

Универзитетеи Јосийа Јурја Шӣросмајера у Осијеку

Правни факулиетеи Осијек

bcincura@pravos.hr

\section{Правно регулисање беспилотних ваздухопловних система у Европској унији са освртом на законодавство Републике Хрватске}

Сажетиак: Бесииилойни ваздухойлови се брзо развијају, а њихова йримена је све щиира. Број корисника бесиилойних ваздухойлова растие йе је йоиребно ускладити и йостиојеће законодавстиво на нивоу ЕУ и одг̄оварајуће изменийи регуулайорни оквир. Рейублика Хрвайска, у складу са развојем нових решена у оквиру Евройске уније, 2018. голдине (Народне новине, број 104/2018) изменила је Правилник о систеемима бесиилотиних ваздухойлова из 2015. г̄oдине (Народне новине, број 49/2015 и 77/2015).

Иако је 'Хрвайска агеениија за цивилно зракойловстиво' навела да је гллавни разлог̄ за израду новог̄ Правилника да се начионални системм йрилаг̄оди будућем систиему Еуройске уније како би се олакщала иримена нове Уредбе о бесиилойним ваздухойловима када она сииуии на снагуу, изненађује чињеница да је Рейублика Хрвайска одлучила изменийи Правилник иррије усвајања Уредбе. Посебно с обзиром на чињенииу да рад на усвајању Уредбе йраје већ неколико гоодина.

Корищћење бесииллойних ваздухойлова свакако ће се щиирийи. Треба,

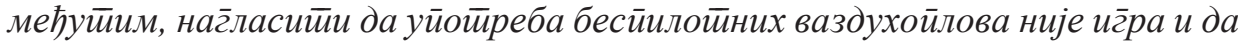
се безбедносна йравила морају йошӣовайи. Прилаг̄ођавање йравног̄ оквира у иильу њег̄овог̄ йобољщиања свакако тиреба иоохвалитии. Остиаје да се види щйиа ће и са каквом динамиком ЕУ урадитии када гооворимо о рег̄улисаюу бес-

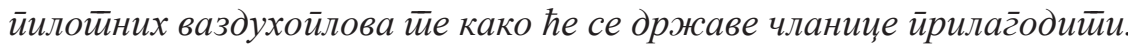

Кључне речи: бесиилотини ваздухойлови, хрвайски Правилник о систиемима бесиичлойних ваздухойлова, Рейублика Хрвайска, Евройска унија, законска регуулатиива.

Датум пријема рада: 28.04.2019. 